\title{
Pyrolysis Behaviours of Microalgae Nannochloropsis gaditana
}

\author{
Michał Adamczyk ${ }^{1} \cdot$ Marcin Sajdak $^{1}$
}

Received: 7 October 2016 / Accepted: 22 June 2017 / Published online: 29 June 2017

(C) The Author(s) 2017. This article is an open access publication

\begin{abstract}
In this study, the pyrolysis behaviours of marine microalgae biomass, Nannochloropsis gaditana, were investigated at three different temperatures $(400,500$, $600^{\circ} \mathrm{C}$ ). Experiments were conducted in the presence of $\mathrm{N}_{2}$ with a flow rate of $50 \mathrm{~cm}^{3} / \mathrm{h}$ using a $1-\mathrm{kg}$ fixed-bed reactor. The effects of pyrolysis conditions such as temperature on product yields were studied. The char, bio-oil, and gaseous samples obtained were analysed for elemental trace metals using inductively coupled plasma atomic emission spectroscopy (ICP-OES) and gas chromatography with mass detection (GC-MS). Raw Nannochloropsis gaditana samples were also analysed by pyrolysis-gas chromatography-mass spectrometry (Py-GC-MS). Mass and energy balances were calculated. The results indicate that the biooil from the pyrolysis of Nannochloropsis gaditana under $600^{\circ} \mathrm{C}$ had the highest heating value $(12.6 \mathrm{MJ} / \mathrm{kg})$ and was obtained with the highest efficiency (38-40\%). Alkanes and alkenes, such as tetradecane, pentadecane, heptadecene, and octadecene, were identified in the liquid products, and the highest contents of alkanes and alkenes were determined in the bio-oil obtained under $500^{\circ} \mathrm{C}$. In these pyrolysis conditions, gaseous products exhibited the highest concentrations of methane (greater than 50\% in the maximum range). These properties of the bio-oil and its gaseous products demonstrated that Nannochloropsis gaditana can be used as a renewable energy resource and chemical feedstock. The biochar from all processes contained almost $70 \%$ ash and, in this particular case, can be used as, for example, a fertilizer because it does not contain any heavy metals.
\end{abstract}

Marcin Sajdak

msajdak@ichpw.pl

1 Institute for Chemical Processing of Coal, 1 Zamkowa St., 41-803 Zabrze, Poland
Keywords Pyrolysis $\cdot$ Biomass $\cdot$ Algae $\cdot$ Nannochloropsis gaditana

\section{Introduction}

Fossil fuels such as coal, oil, and natural gas are currently the primary sources of energy globally. Experts anticipate that fossil fuels will be depleted within the next 50 years. In addition, the increasing use of fossil fuels in the energy sector, and for industry and transportation, is negatively impacting the climate and the environment [1]. One major issue is the greenhouse effect that results from the emission of greenhouse gases, e.g., carbon dioxide and methane. More than $90 \%$ of the carbon dioxide emitted to the atmosphere is associated with the processing of fossil fuels. Moreover, the processing of coal and oil leads to significant emissions of nitrogen oxides and sulphur oxides. According to the Kyoto Protocol, fossil fuels should be replaced by other new energy sources, such as biomass, hydrogen, and renewable energy [1-3].

Biomass is an alternative source of renewable energy. Biomass is widely available worldwide, and it can easily be used to produce "green" energy. Biomass can be divided into plant biomass and animal biomass. Plant biomass is derived from microalgae, crops, seaweed, forests, and the materials remaining from agricultural and forestry processes [4]. Forest biomass, agricultural residues, and energy crops are the major sources of renewable energy in Europe and the United States. The European policy assumes that increased biomass will be applied to energy production in the near future. Over the course of 17 years, from 1990 to 2007, the global production of energy from biomass significantly increased from 190 to 3238 MW. The European Union estimates that $56 \%$ of the global renewable energy 
will originate from biomass by 2020 . It is estimated that energy crops will constitute a major part of the bioenergy sources. Energy resources from energy crops will increase from $0.8-2.0 \mathrm{EJ} / \mathrm{yr}$ (2010) to 4.3-6.0 EJ/yr in 2030 and that from agricultural residues will increase from $0.8-3.9 \mathrm{EJ} / \mathrm{yr}$ (2010) to $0.6-5.0 \mathrm{EJ} / \mathrm{yr}$ in 2050. Energy resources from forest biomass have been estimated to be $0.8-10.6 \mathrm{EJ} / \mathrm{yr}[5,6]$.

One of the most promising renewable sources of energy is algae biomass. Algae are photosynthetic plant organisms that can rapidly increase their community mass. The energetic utilization of algae can be divided into three groups. Heterotrophic algae are able to take up organic molecules from their external environment and convert these molecules into proteins and fatty acids. Autotrophic algae are able to conduct photosynthesis to harness sunlight and fix the inorganic carbon from atmospheric $\mathrm{CO}_{2}$. During photosynthesis, algae synthesize sugars through many biochemical transformations. Mixotrophic algae may simultaneously conduct photosynthesis and obtain organic molecules. Photosynthetic algae have the potential to utilize $\mathrm{CO}_{2}$ emissions and offer the potential for a carbon-neutral biofuel. Based on their morphology and size, algae can be divided into two groups: macroalgae and microalgae. Macroalgae are composed of multiple cells and can form structures such as roots, stems, and leaves. Macroalgae are frequently used in the food industry. Microalgae are microscopic, mainly unicellular, plant organisms characterized by their rapid growth rates, effective biofixation of carbon dioxide, and rich lipid contents. Depending on the species, the lipid content of the cells of microalgae can range from 10 to $70 \%$. It is assumed that microalgae can utilize $1.8 \mathrm{~kg}$ of carbon dioxide per $1 \mathrm{~kg}$ of dry biomass [7-10]. Algae biomass can be used for many processes, such as combustion, gasification, pyrolysis, and digestion. Anaerobic digestion of algae biomass allows for the production of bioethanol and biogas [7, 11]. However, algae biomass is most commonly used for the production of biodiesel. Based on their high productivity and lipid content, microalgae are an alternative source of biomass for the production of biodiesel. There are several possibilities for obtaining biodiesel from algae, e.g., chemical/mechanical extraction or thermic conversion of biomass. After isolation, the crude oil must then be subjected to transesterification and purification [12-14].

This type of biomass is recognized as an energy crop or feedstock for biorefineries, and according to studies, macroalgae or seaweed can also be viewed as a waste problem when it is spontaneously deposited on shorelines, creating hygienic problems. Often, the proposed solution is to utilize this waste in thermal processing applications that include combustion, gasification, and pyrolysis. Many authors have focused on the kinetics and thermal characterization of microalgae and marine biomass, and as a result these aspects have been widely studied [15-20].
Pyrolysis is the thermal degradation of materials in the absence of oxygen. Pyrolysis is a promising thermic process for obtaining liquid products. In this process, the quantity and quality of the biochars, bio-oil, and gaseous products depend on the pyrolysis conditions, e.g., the pyrolysis temperature, gas flow rate, pressure, and heating rate, and the particle size of the material used in the process [15, 21-24]. Algae biomass contains a large amount of lipids; therefore, pyrolysis can be used to extract bio-oil. Moreover, the resulting charcoal can be used as a sorbent, fertilizer, or fuel, and the gas can be used as a gaseous fuel. The aim of this work is to evaluate the fixed-bed pyrolysis of the marine microalgae Nannochloropsis gaditana under different temperature conditions. The resulting charcoal, liquid products, and gas have been analysed in detail. This paper also gives information regarding the degree of energy self-sufficiency of the biomass pyrolysis process depending on the biomass humidity content, directly informing the literature, which otherwise contains no available information concerning the direct pyrolysis of microalgae.

\section{Materials and Methods}

The microalgae $N$. gaditana was prepared by drying to 2-5\% humidity $\left(\mathrm{W}_{\mathrm{t}}^{\mathrm{r}}\right)$. Next, the microalgae samples were placed in a steel retort and then pyrolysed under a nitrogen atmosphere. Nitrogen was pumped into the retort from the bottom at a flow rate of $50 \mathrm{~cm}^{3} / \mathrm{h}$. Prior to pyrolysis, the sample was purged with nitrogen for $10-15 \mathrm{~min}$, and then the sample was heated to the aforementioned temperature at a heating rate of $20 \mathrm{~K} / \mathrm{min}$. The pyrolysis process was conducted three times for each temperature of interest (400, $\left.500,600^{\circ} \mathrm{C}\right)$. After reaching the desired temperature, each sample was maintained under the experimental conditions for $30 \mathrm{~min}$ before cooling to room temperature. Figure 1 presents a schematic of the laboratory-scale setup applied to the presented research. During the process, char, liquid, and gaseous samples were collected for further analysis. All processes were performed in triplicate to ensure that the reactions were repeatable and stable.

Pyrolysis was conducted as a batch process using a processing furnace supplied by the IZO Company (Poland). The furnace was equipped with a stainless steel retort ( $0.24 \mathrm{~m}$ in height and $0.07 \mathrm{~m}$ in diameter). The temperature maximum of the furnace model was $1500^{\circ} \mathrm{C}$, and its settings could be controlled to within $\pm 5^{\circ} \mathrm{C}$. The furnace was equipped with a thermocouple that extended into the retort, and both the furnace and the retort temperatures could be read continuously. To control the temperature, two type $\mathrm{S}$ thermocouples (PtRh10\%-Pt) were used. The thermocouples were maintained in the retort axis at the positions of approximately $1 / 3$ and $2 / 3$ of the retort height. 
Fig. 1 Schematic of the laboratory setup for the thermal conversion of biomass and PP blends [25]

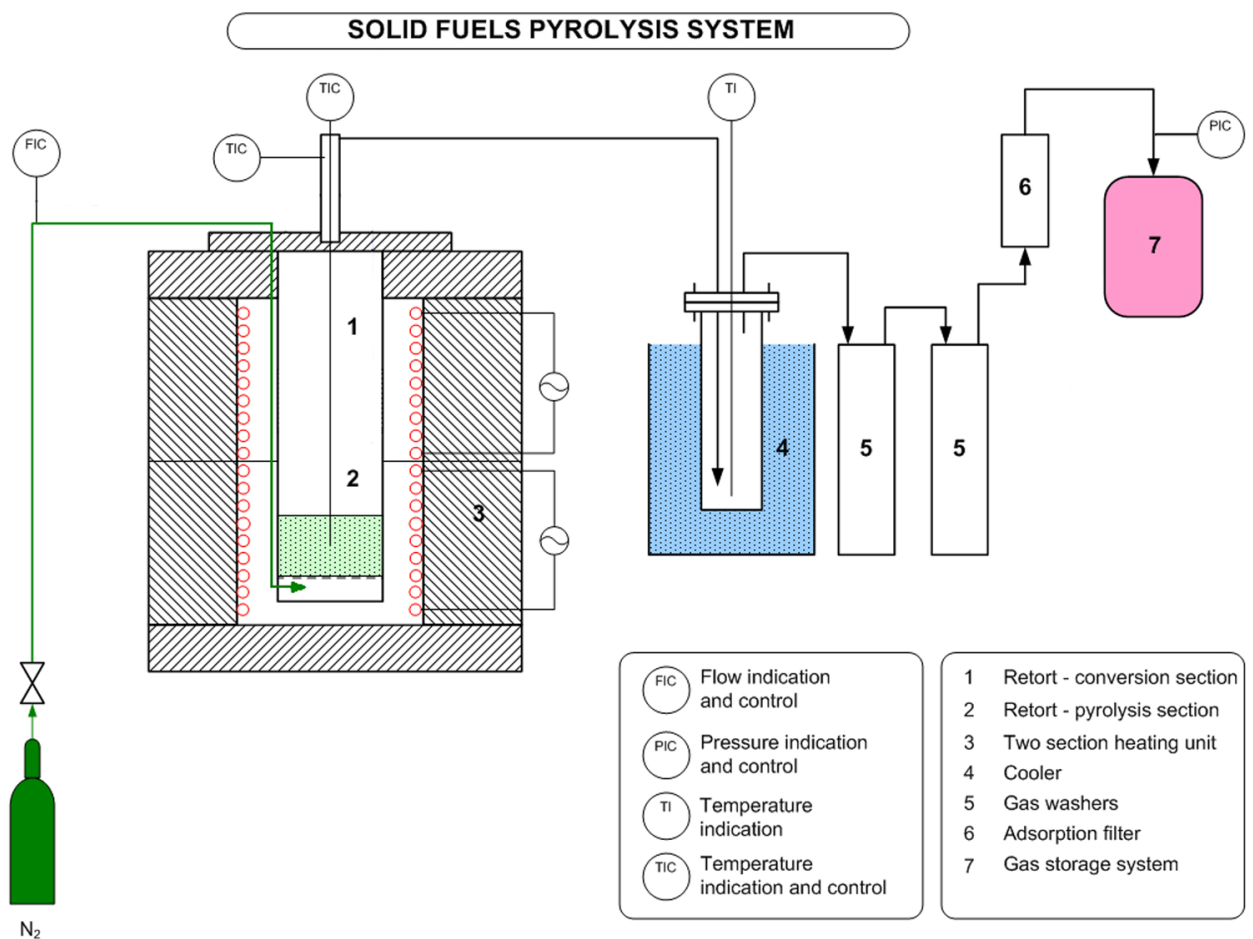

The required heating rate and nearly constant temperature conditions of pyrolysis were achieved using a temperature control system. The heating rate can, in general, be set at $1-50{ }^{\circ} \mathrm{C} / \mathrm{min}$ by varying the number of ramps, controlled directly by the control system. The sample size was generally between 100 and $200 \mathrm{~g}$, but this value depended on the density of the material that was used for the pyrolysis. The retort was purged with $\mathrm{N}_{2}$ at a rate of $50 \mathrm{~cm}^{3} / \mathrm{h}$, which was controlled by mass flow controllers. The bio-oil was collected in a set of laboratory glass bottles (approximately $100 \mathrm{~mL}$ ) connected in series. All glass bottles were chilled to a temperature of approximately $0^{\circ} \mathrm{C}$ in a cooling bath (ethylene glycol) using refrigerated circulators. The gaseous products were directly analysed using an extractive gas analyser (SICK. USA).

\section{Analytical Procedures}

\section{Proximate Analysis}

Volatile Matter Content Determination Using a Gravimetric Method [26] The volatile matter content (VM) was determined by weighing an open crucible without air at $850 \pm 15^{\circ} \mathrm{C}$ for $7 \mathrm{~min}$. Then, the difference between the total weight loss and weight loss due to the evaporation of water was calculated.

Ash Content Determination [27] The ash content was determined by incinerating the samples in a muffle furnace, which consisted of heating the samples in air at a specific rate to a temperature of $815 \pm 10^{\circ} \mathrm{C}$ and maintaining this temperature until a constant weight was reached.

\section{Ultimate Analysis}

Determination of Carbon, Hydrogen, Nitrogen, and Sulphur Contents [28] The samples were subjected to an automated quantitative combustion process in an oxygen stream at $1150{ }^{\circ} \mathrm{C}$ and then transferred through a quartz bridge into a reduction tube in which the sulphur and nitrogen oxides were reduced to $\mathrm{SO}_{2}$ and $\mathrm{N}_{2}$ in the presence of copper. The combustion gases at the reduction tube outlet were transferred into a dynamic separation system in which the absorption columns were desorbed thermally in sequence. These gases $\left(\mathrm{N}_{2}, \mathrm{CO}_{2}, \mathrm{H}_{2} \mathrm{O}\right.$, and $\left.\mathrm{SO}_{2}\right)$ were identified using a thermal conductivity detector (TCD). Low $\mathrm{SO}_{2}$ concentrations were analysed using an NDIR detector.

Determination of Oxygen Content [28] Direct quantitative analysis of the oxygen content was performed by pyrolysing a sample under an $\mathrm{H}_{2} \mathrm{O}-, \mathrm{CO}_{2-}$, and $\mathrm{O}_{2}$-free reductive atmosphere $\left(95 \% \mathrm{~N}_{2}\right.$ and $\left.5 \% \mathrm{H}_{2}\right)$ at $1120-1150{ }^{\circ} \mathrm{C}$. The sample was placed in a pyrolysis tube filled with elemental carbon, and carbon dioxide was obtained as a result of the reaction between the oxygen in the sample and carbon from the filling (Boudouard equilibrium). The acidic pyrolysis products, such as $\mathrm{H}_{2} \mathrm{~S}, \mathrm{HCN}$, and $\mathrm{HCl}$, were absorbed by granulated $\mathrm{NaOH}$, and the produced water was absorbed by 
a dehumidifier. The inert pyrolysis products $\left(\mathrm{N}_{2}\right.$ and $\left.\mathrm{CH}_{4}\right)$ were directed into a measurement cell with carbon monoxide. Because the NDIR detector was sensitive only to CO, the other gases did not have to be separated. The elementary $\mathrm{C}_{\mathrm{t}}^{\mathrm{a}}, \mathrm{H}_{\mathrm{t}}^{\mathrm{a}}, \mathrm{N}^{\mathrm{a}}, \mathrm{S}_{\mathrm{t}}^{\mathrm{a}}$, and $\mathrm{O}_{\mathrm{t}}^{\mathrm{a}}$ compositions were measured using a Vario MACRO Cube automatic elemental analyser. All values of measurement uncertainty for the carbon, oxygen, nitrogen, hydrogen, and sulphur concentrations are presented in Table 1.

Higher Heating Values of Fuels The high heating values in our studies were calculated from the elemental composition using the Milne [29] approach according to Eq. (1):

$$
\begin{aligned}
H H V_{\text {Milne }}= & 0.341 \cdot \mathrm{C}+1.322 \cdot \mathrm{H}-0.12 \cdot \mathrm{O}-0.12 \cdot \mathrm{N} \\
& +0.0686 \cdot \mathrm{S}-0.0153 \cdot \text { ash. }
\end{aligned}
$$

Determination of Properties of the Liquid and Gaseous Fractions The properties of the gaseous fraction were analysed using a $\mathrm{CO}, \mathrm{CO}_{2}, \mathrm{H}_{2}$, and $\mathrm{CH}_{4}$ automatic gas analyser. GC analyses were performed with a Varian CP-3800 gas chromatograph with FID and TCD detectors and a $100 \%$ dimethylpolysiloxane $(60 \mathrm{~m}, 0.25 \mathrm{~mm}$ i.d., $0.25 \mu \mathrm{m}$ film thickness) capillary column. The chromatographic programme included: $45^{\circ} \mathrm{C}$ for $2 \mathrm{~min}$, then a programmed temperature ramp to $160^{\circ} \mathrm{C}$ (heating rate $8{ }^{\circ} \mathrm{C} / \mathrm{min}$ to $90^{\circ} \mathrm{C}$, then $20^{\circ} \mathrm{C} / \mathrm{min}$ to $160^{\circ} \mathrm{C}$ ). Helium was used as the carrier gas $(1.0 \mathrm{~mL} / \mathrm{min})$. The calorific value of the gaseous fraction was calculated according to the calorific value of the partial gas components. In the case of liquid fraction analysis, the GC analyses were performed with a Trace Ultra Thermo Scientific gas chromatograph with FID and a Crossbond polyethylene glycol $(60 \mathrm{~m}, 0.35 \mathrm{~mm}$ i.d., $0.5 \mu \mathrm{m}$ film thickness) capillary column. The chromatographic programme included: $50^{\circ} \mathrm{C}$ for $5 \mathrm{~min}$, then a programmed temperature ramp to $200^{\circ} \mathrm{C}$ (heating rate $10^{\circ} \mathrm{C} / \mathrm{min}$ to $200^{\circ} \mathrm{C}$ ). Helium was also used as the carrier gas in this case $(2.5 \mathrm{~mL} / \mathrm{min})$. The liquid products due to the sample's heterogeneous character were dissolved in isopropanol in order to standardize the samples. This chromatograph with Crossbond polyethylene glycol column allows the light organic compounds to be analysed.

Pyrolysis-gas chromatography-mass spectrometry (Py-GC-MS) was used to study the impact of temperature on the chemical component released under temperature. Py-GC-MS experiments were performed using a CDS 5200 HPR (pyroprobe) coupled to a PerkinElmer Clarus $680 \mathrm{GC}-\mathrm{MS} / \mathrm{FID}$ in the following five temperature ranges:

- to $200^{\circ} \mathrm{C}$,

- $200-300^{\circ} \mathrm{C}$,

- $300-400^{\circ} \mathrm{C}$,

- $400-500^{\circ} \mathrm{C}$, and

- $500-600^{\circ} \mathrm{C}$.

Determination of the Trace Metals Trace elements in the $N$. gaditana biomass were analysed using an ICP-OES analyser. Inductively coupled plasma optical emission spectrometry is based on the study of atomic spectra. The inductively coupled plasma is used to produce excited atoms and ions that emit electromagnetic radiation at wavelengths characteristic of a particular element. The temperature in the electromagnetic field is in the range from 6000 to $10,000 \mathrm{~K}$. The determination of the trace metals includes the following steps: conducting solid and liquid samples into aqueous solutions, organic matter removal, and ICP-OES spectrometer analysis. Emission spectrometric analysis is preceded by spectrometer calibration by measuring the radiation emission characteristic of the individual elements of the standard solutions and blanks. The sample solution is taken in for analysis using a peristaltic pump. The pump provides a constant flow of the sample into the sputtering chamber by a nebulizer. The aerosolised sample is injected into the canter of the plasma, at which point the atoms are excited. As a result of returning the excited atoms to their original state, radiation is emitted. The radiation beam is directed to
Table 1 Feedstock characterization: elemental composition, ash content (wt\%), and $\mathrm{HHV}(\mathrm{MJ} / \mathrm{kg})$ calculated on a dry basis

\begin{tabular}{lcccc}
\hline Biomass & $\begin{array}{l}\text { Nannochloropsis } \\
\text { gaditana }\end{array}$ & $\begin{array}{l}\text { Nannochloropsis } \\
\text { gaditana [21] }\end{array}$ & $\begin{array}{l}\text { Scenedesmus alm- } \\
\text { eriensis [21] }\end{array}$ & $\begin{array}{l}\text { Measure- } \\
\text { ment uncer- } \\
\text { tainty }\end{array}$ \\
\hline Ash (\%) & 31.4 & 12.4 & 16.8 & 0.2 \\
Carbon content (\%) & 42.9 & 47.6 & 38.0 & 0.5 \\
Nitrogen content (\%) & 6.7 & 6.9 & 5.5 & 0.15 \\
Hydrogen content (\%) & 6.8 & 7.5 & 5.6 & 0.2 \\
Sulphur content (\%) & 0.4 & 0.5 & 0.5 & 0.03 \\
Oxygen content $^{\mathrm{a}}(\%)$ & 11.6 & 25.1 & 30.4 & 0.1 \\
HHV $_{\text {MILE }}(\mathrm{MJ})$ & 21.5 & 23.1 & 16.8 & - \\
\hline
\end{tabular}

${ }^{\mathrm{a} B y}$ difference 
the spectrometer. The beam is split and directed to the CID detector.

\section{Results and Discussion}

The algae biomass used in this study is characterized by a relatively large ash content compared to other such (strains) biomass samples; however, its higher heating value was greater than $21 \mathrm{MJ}$. The $N$. gaditana microalgae sample used in the pyrolysis process, and all of the products obtained through this process, was subjected to basic analyses, including

- ash content (Ash),

- volatile matter content (VM),

- ultimate analysis $\left(\mathrm{C}_{\mathrm{a}}, \mathrm{H}_{\mathrm{a}}{ }^{\mathrm{t}}, \mathrm{N}_{\mathrm{a}}, \mathrm{S}_{\mathrm{a}}^{\mathrm{t}}\right.$, and $\left.\mathrm{O}_{\mathrm{a}}^{\mathrm{t}}\right)$, and

- trace metals $\left(\mathrm{As}^{\mathrm{d}}, \mathrm{Cd}^{\mathrm{d}}, \mathrm{Co}^{\mathrm{d}}, \mathrm{Cr}^{\mathrm{d}}, \mathrm{Cu}^{\mathrm{d}}, \mathrm{Mn}^{\mathrm{d}}, \mathrm{Mo}^{\mathrm{d}}, \mathrm{Ni}^{\mathrm{d}}\right.$, $\mathrm{Pb}^{\mathrm{d}}, \mathrm{Sb}^{\mathrm{d}}, \mathrm{V}^{\mathrm{d}}, \mathrm{Zn}^{\mathrm{d}}, \mathrm{Hg}^{\mathrm{d}}$ )

according to the methods previously described here and the methods reported in [25].

The physical and chemical properties of the algae biomass used in this study are presented in Tables 1 and 2 . Table 3 presents the results of the proximate analysis of raw biomass and biochars obtained under different pyrolysis conditions.

The biomass samples were pyrolysed at three temperatures $\left(400,500\right.$, and $\left.600^{\circ} \mathrm{C}\right)$ to determine the effects of temperature on the products. The efficiencies of the processes were calculated according to Eq. (2) and are shown in Fig. 2:

Table 2 Feedstock characterization: trace metals (ICP-OES) calculated on a dry basis

\begin{tabular}{llll}
\hline Symbol & Unit & Result & $\begin{array}{l}\text { Measure- } \\
\text { ment uncer- } \\
\text { tainty }\end{array}$ \\
\hline $\mathrm{As}^{\mathrm{d}}$ & $\mathrm{mg} / \mathrm{kg}$ & 0.309 & 0.102 \\
$\mathrm{Cd}^{\mathrm{d}}$ & $\mathrm{mg} / \mathrm{kg}$ & $<0.05$ & 0.012 \\
$\mathrm{Co}^{\mathrm{d}}$ & $\mathrm{mg} / \mathrm{kg}$ & $<0.06$ & 0.019 \\
$\mathrm{Cr}^{\mathrm{d}}$ & $\mathrm{mg} / \mathrm{kg}$ & 1.02 & 0.235 \\
$\mathrm{Cu}^{\mathrm{d}}$ & $\mathrm{mg} / \mathrm{kg}$ & 9.99 & 1.00 \\
$\mathrm{Mn}^{\mathrm{d}}$ & $\mathrm{mg} / \mathrm{kg}$ & 116 & 10 \\
$\mathrm{Mo}^{\mathrm{d}}$ & $\mathrm{mg} / \mathrm{kg}$ & 1.06 & 0.35 \\
$\mathrm{Ni}^{\mathrm{d}}$ & $\mathrm{mg} / \mathrm{kg}$ & 0.407 & 0.08 \\
$\mathrm{~Pb}^{\mathrm{d}}$ & $\mathrm{mg} / \mathrm{kg}$ & 1.46 & 0.26 \\
$\mathrm{Sb}^{\mathrm{d}}$ & $\mathrm{mg} / \mathrm{kg}$ & $<0.500$ & 0.140 \\
$\mathrm{~V}^{\mathrm{d}}$ & $\mathrm{mg} / \mathrm{kg}$ & 0.498 & 0.139 \\
$\mathrm{Zn}^{\mathrm{d}}$ & $\mathrm{mg} / \mathrm{kg}$ & 58.8 & 8.2 \\
$\mathrm{Hg}^{\mathrm{d}}$ & $\mathrm{ppm}$ & 0.014 & \\
\hline
\end{tabular}

d calculated on a dry basis
Table 3 Results of proximate analysis of raw biomass and biochars (wt $\%$ as-received)

\begin{tabular}{llllrr}
\hline $\begin{array}{l}\text { Process con- } \\
\text { ditions }\left({ }^{\circ} \mathrm{C}\right)\end{array}$ & $\mathrm{A}(\%)$ & $\mathrm{M}(\%)$ & $\mathrm{V}_{\mathrm{m}}(\%)$ & $\mathrm{F}_{\mathrm{c}}{ }^{\mathrm{a}}(\%)$ \\
\hline & Raw biomass & 28.3 & 4.1 & 62.5 & 5.1 \\
400 & Biochar & 65.6 & 2.8 & 6.2 & 25.4 \\
500 & & 68.5 & 2.3 & 4.5 & 24.7 \\
600 & & 68.6 & 2.5 & 3.2 & 25.7 \\
\hline
\end{tabular}

$A$ ash, $M$ moisture, $V_{m}$ volatile matter, $F_{c}$ fixed carbon

${ }^{\mathrm{a}}$ Calculated by difference

$W_{i j}=\frac{M_{j}}{M} \times 100 \%$,

where $W_{i j}$ is the pyrolysis process efficiency $(i)$ for the $j$ th fraction (solid, liquid, gas), $M_{j}$ is the weight of the $j$ th fraction (solid, liquid, gas), and $M$ is the weight of the mixed batch used in the process (pyrolysis).

The effects of increasing the temperature on the concentrations of liquid products in the pyrolysis test occurred at the expense of reducing the amount of gaseous products (Fig. 2). This is a highly desirable phenomenon with regard to the possibility of using algae biomass for the generation of liquid fuels via thermal conversion. For the marine biomass tested in this research, the yield of liquid product obtained under $500^{\circ} \mathrm{C}$ was approximately $17 \%$ higher (Fig. 1) than that obtained under $400^{\circ} \mathrm{C}$. Higher yields were also observed for the carbon concentration and heat of combustion of the liquid products, by 13.4 and $7.2 \%$, respectively (Table 4). A similar dependence was observed in the fixed-bed pyrolysis of marine algae biomass. In the slow pyrolysis of Saccharina japonica, a greater number of liquid products were observed with increasing pyrolysis temperature [30]. After the fixed-bed pyrolysis of S. japonica $\left(470^{\circ} \mathrm{C}\right), 37.9 \%$ of the liquid products were obtained [31]. The amount of liquid products obtained from the slow pyrolysis of $S$. japonica was similar to its pyrolysis at $500{ }^{\circ} \mathrm{C}$ in our study. In Table 3 , the elemental analysis results and energy balance for each product in relation to the biomass processed via pyrolysis are presented. The heating value of the liquid products calculated for a temperature of $500^{\circ} \mathrm{C}$ gave a similar heating value of liquid products from the process of slow pyrolysis $\left(450{ }^{\circ} \mathrm{C}\right)$ for two other species of microalgae, Scenedesmus and Spirulina. The heating value of the liquid products obtained from the pyrolysis of $N$. gaditana at $500{ }^{\circ} \mathrm{C}$ reached $31.8 \mathrm{MJ} /$ $\mathrm{kg}$, whereas the pyrolysis of Scenedesmus and Spirulina at $450^{\circ} \mathrm{C}$ gave the values of 36.7 and $35.2 \mathrm{MJ} / \mathrm{kg}$, respectively. The ratios of the pyrolytic products were similar for all three species of microalgae [32]. 
Fig. 2 Efficiencies of the pyrolysis processes

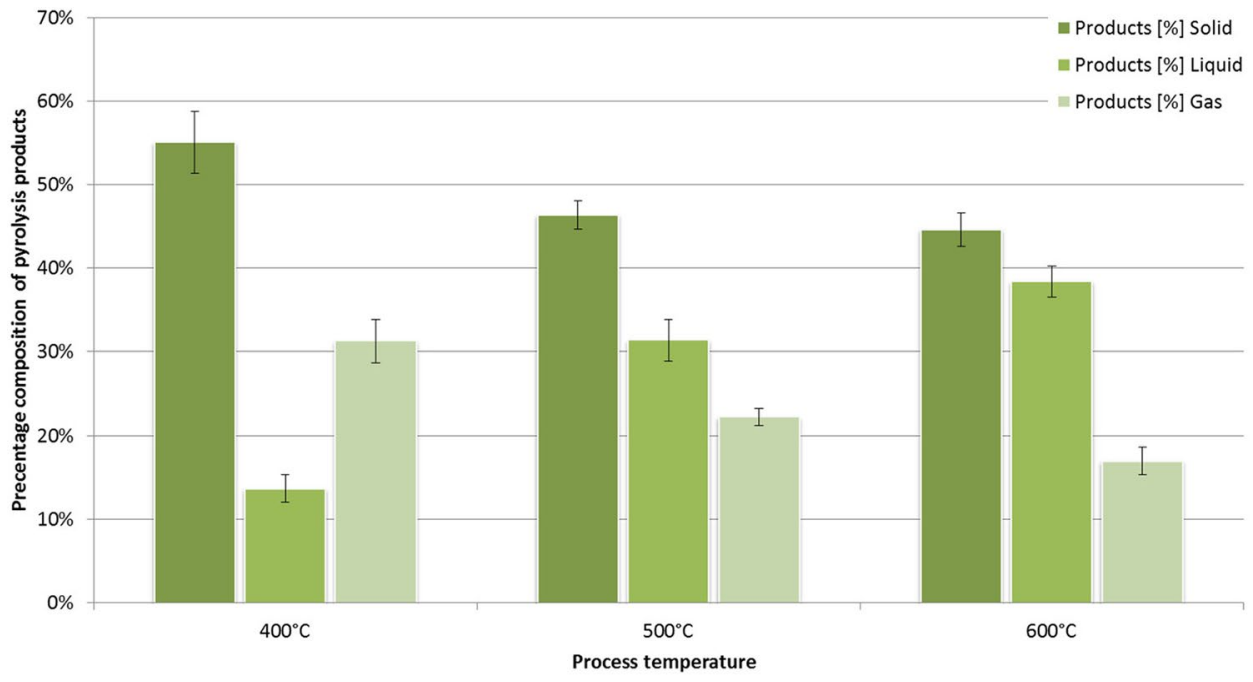

Table 4 Elements and energy balance of products obtained in the pyrolysis process (in wt $\%$ dry ash free)

\begin{tabular}{|c|c|c|c|c|c|c|c|c|}
\hline $\begin{array}{l}\text { Process condi- } \\
\text { tions }\left({ }^{\circ} \mathrm{C}\right)\end{array}$ & & Carbon content & $\begin{array}{l}\text { Nitrogen } \\
\text { content }\end{array}$ & $\begin{array}{l}\text { Hydrogen } \\
\text { content }\end{array}$ & $\begin{array}{l}\text { Sulphur } \\
\text { content }\end{array}$ & Oxygen content & Total & $\mathrm{HHV}_{\text {MILE }}$ \\
\hline & Raw biomass & 62.6 & 9.8 & 10.0 & 0.7 & 16.9 & 100.0 & 31.4 \\
\hline \multirow[t]{4}{*}{400} & Biochar & 28.1 & 3.9 & 1.3 & 0.7 & 1.9 & 35.8 & 10.8 \\
\hline & Liquid & 24.6 & 5.9 & 0.4 & 0.0 & 7.5 & 38.4 & 7.6 \\
\hline & Gas & 10.0 & 0.0 & 8.3 & 0.0 & 7.6 & 25.9 & 13.0 \\
\hline & Total & 62.7 & 9.8 & 10.0 & 0.7 & 16.9 & 100.1 & 31.4 \\
\hline \multirow[t]{4}{*}{500} & Biochar & 22.7 & 2.8 & 0.7 & 0.2 & 0.8 & 27.1 & 8.5 \\
\hline & Liquid & 33.0 & 7.0 & 0.4 & 0.5 & 12.1 & 52.9 & 9.8 \\
\hline & Gas & 6.9 & 0.0 & 9.0 & 0.0 & 4.1 & 20.0 & 13.0 \\
\hline & Total & 62.6 & 9.8 & 10.0 & 0.7 & 16.9 & 100.0 & 31.4 \\
\hline \multirow[t]{4}{*}{600} & Biochar & 22.8 & 2.4 & 0.5 & 0.2 & 0.2 & 26.2 & 8.5 \\
\hline & Liquid & 34.8 & 7.4 & 2.4 & 0.5 & 14.0 & 59.1 & 12.6 \\
\hline & Gas & 4.9 & 0.0 & 7.2 & 0.0 & 2.6 & 14.7 & 10.4 \\
\hline & Total & 62.6 & 9.8 & 10.0 & 0.7 & 16.9 & 100.0 & 31.4 \\
\hline
\end{tabular}

The increase of carbon content in the liquid products is associated with an intensification of the thermal degradation process of the solid fraction into easily condensable organic compounds (decreased quantities of gas). This process qualitatively and quantitatively influences the characteristics of the liquid products obtained during the thermal conversion of algae at 400 and $500^{\circ} \mathrm{C}$. These changes are presented as chromatograms in Fig. 3 and in tabular form in Table 5.

As can easily be observed (Fig. 3), the intensification of the thermal conversion process has a significant effect on the characteristics of the liquid products obtained from the investigated biomass. For the liquid products obtained at $400^{\circ} \mathrm{C}$, the qualitative and quantitative gas chromatography analyses were able to determine the concentrations of six organic compounds, namely acetone, methanol, ethylbenzene, $n$-pentadecane, $n$-pentadecene, and furfuryl alcohol. In comparison with the pyrolysis of seaweeds (Enteromorpha clathrata and Sargassum natans) [33], the typical compounds derived from the decomposition of lignins (e.g., phenol) or lipids (e.g., $n$-pentadecane, $n$-pentadecene) were identified.

Increasing the pyrolysis temperature to $500{ }^{\circ} \mathrm{C}$ influences the composition of the liquid products, which made it possible to qualitatively and quantitatively determine the next 11 compounds. Table 5 presents the concentration of each of the analysed compounds and the differences in concentration between the liquid fractions obtained at 400 and $500^{\circ} \mathrm{C}$. For methanol and $n$-pentadecene, the concentration in the liquid fraction obtained at $500{ }^{\circ} \mathrm{C}$ was lower than that obtained at the lower temperature. This result can be associated with the breakage of double bonds that occurred 

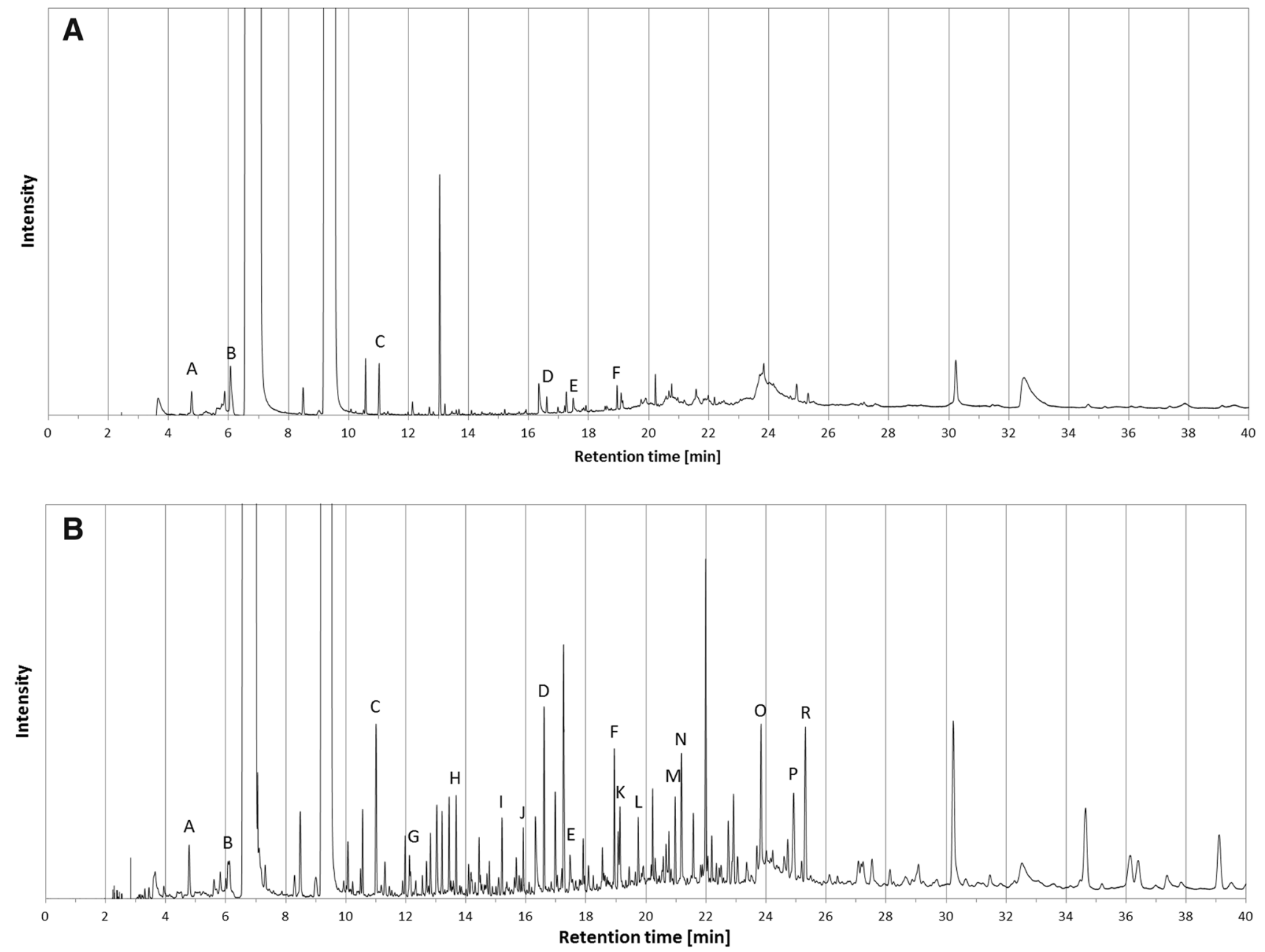

Fig. 3 Identified VOCs, alkanes, and alkenes in the liquid products (under $\mathbf{a} 400^{\circ} \mathrm{C}$ and $\mathbf{b} 500^{\circ} \mathrm{C}$ ) using a gas chromatograph. $A$ acetone, $B$ methanol, $C$ ethylbenzene, $D$ dodecane, $E$ styrene, $F n$-tetradecane,
$G n$-tetradecene, $H n$-pentadecane, $E n$-pentadecene, $I$ furfuryl alcohol, $J n$-heptadecane, $K n$-heptadecene, $L$ octadecane, $M$ hydroxyacetophenone, $N$ phenol, $O$ ethylphenol, $P$ 4-methylphenol

gaseous products to decrease by $7 \%$ and, at the same time, the calorific value of process gas was increased by $0.7 \%$.

In the subsequent studies, we increased the pyrolysis temperature by $100^{\circ} \mathrm{C}$, which resulted in a further increase in the volume of the liquid fraction to $37 \%$ (an increase of $6 \%$ ). We also observed 9-10\% bio-oil increases compared to the heat of combustion for the fraction obtained at $500{ }^{\circ} \mathrm{C}$, which was due to the increase of the carbon and hydrogen contents in the final product. Further analysis and comparison of the properties of the bio-oil obtained at $600{ }^{\circ} \mathrm{C}$ to the bio-oil properties obtained at $500^{\circ} \mathrm{C}$ clearly revealed that the increase in the heat of combustion was associated with an increase in the content of methanol in the liquid fraction (a fourfold increase). As can be observed in the chromatograms (Fig. 6), the quality of the liquid fraction in the present case did not significantly change. In addition to the increase in the methanol content, the 
Table 5 Concentrations of alkanes and alkenes in the liquid products (and differences between them) at 400 and $500{ }^{\circ} \mathrm{C}$ obtained via gas chromatography

\begin{tabular}{llllr}
\hline & Id identified chemical compound & $\begin{array}{l}\text { Pyrolysis } 400^{\circ} \mathrm{C}- \\
\text { concentration }(\mathrm{mg} / \mathrm{g})^{\mathrm{a}}\end{array}$ & $\begin{array}{l}\text { Pyrolysis } 500^{\circ} \mathrm{C}- \\
\text { concentration }(\mathrm{mg} / \mathrm{g})^{\mathrm{a}}\end{array}$ & Differences \\
\hline $\mathrm{A}$ & Acetone & 0.37 & 0.48 & 0.11 \\
$\mathrm{~B}$ & Methanol & 1.07 & 0.52 & -0.55 \\
$\mathrm{C}$ & Ethylbenzene & 0.60 & 0.77 & 0.17 \\
$\mathrm{D}$ & $n$-Pentadecane & 0.15 & 1.06 & 0.91 \\
$\mathrm{E}$ & $n$-Pentadecene & 0.28 & 0.20 & -0.08 \\
$\mathrm{~F}$ & Furfuryl alcohol & 0.22 & 0.70 & 0.48 \\
$\mathrm{G}$ & $n$-Dodecane & - & 0.21 & 0.21 \\
$\mathrm{H}$ & Styrene & - & 0.32 & 0.32 \\
$\mathrm{I}$ & $n$-Tetradecane & - & 0.28 & 0.28 \\
$\mathrm{~J}$ & $n$-Tetradecene & - & 0.22 & 0.22 \\
$\mathrm{~K}$ & $n$-Heptadecane & - & 0.31 & 0.31 \\
$\mathrm{~L}$ & $n$-Heptadecene & - & 0.30 & 0.3 \\
$\mathrm{M}$ & Octadecene & - & 0.38 & 0.38 \\
$\mathrm{~N}$ & Hydroxyacetophenone & - & 0.71 & 0.71 \\
$\mathrm{O}$ & Phenol & - & 0.97 & 0.97 \\
$\mathrm{P}$ & Ethylphenol & - & 0.70 & 0.7 \\
$\mathrm{R}$ & 4-Methylphenol & - & 1.17 & 1.17 \\
\hline
\end{tabular}

${ }^{\mathrm{a}}$ Milligram per gram of liquid products

\begin{tabular}{llllr}
\hline & Id identified chemical compound & $\begin{array}{l}\text { Pyrolysis } 500^{\circ} \mathrm{C}- \\
\text { concentration }(\mathrm{mg} / \mathrm{g})^{\mathrm{a}}\end{array}$ & $\begin{array}{l}\text { Pyrolysis } 600{ }^{\circ} \mathrm{C}- \\
\text { concentration }(\mathrm{mg} / \mathrm{g})^{\mathrm{a}}\end{array}$ & Differences \\
\hline $\mathrm{A}$ & Acetone & 0.48 & 0.43 & -0.05 \\
$\mathrm{~B}$ & Methanol & 0.52 & 2.13 & 1.61 \\
$\mathrm{C}$ & Ethylbenzene & 0.77 & 0.85 & 0.08 \\
$\mathrm{D}$ & $n$-Pentadecane & 1.06 & 1.09 & 0.03 \\
$\mathrm{E}$ & $n$-Pentadecene & 0.20 & 0.17 & -0.03 \\
$\mathrm{~F}$ & Furfuryl alcohol & 0.70 & 0.82 & 0.12 \\
$\mathrm{G}$ & $n$-Dodecane & 0.21 & 0.17 & -0.04 \\
$\mathrm{H}$ & Styrene & 0.32 & 0.41 & 0.09 \\
$\mathrm{I}$ & $n$-Tetradecane & 0.28 & 0.21 & -0.07 \\
$\mathrm{~J}$ & $n$-Tetradecene & 0.22 & 0.20 & -0.02 \\
$\mathrm{~K}$ & $n$-Heptadecane & 0.31 & 0.26 & -0.05 \\
$\mathrm{~L}$ & $n$-Heptadecene & 0.30 & 0.21 & -0.09 \\
$\mathrm{M}$ & Octadecene & 0.38 & 0.26 & -0.12 \\
$\mathrm{~N}$ & Hydroxyacetophenone & 0.71 & 0.59 & -0.12 \\
$\mathrm{O}$ & Phenol & 0.97 & 0.86 & -0.11 \\
$\mathrm{P}$ & Ethylphenol & 0.70 & 0.71 & 0.01 \\
$\mathrm{R}$ & 4-Methylphenol & 1.17 & 0.98 & -0.19 \\
\hline
\end{tabular}

${ }^{\mathrm{a}}$ Milligram per gram of liquid products
Table 6 Concentrations of alkanes and alkenes in the liquid products (and differences between them) at 500 and $600{ }^{\circ} \mathrm{C}$ obtained via gas chromatography quantitative analysis revealed a slight decrease in the contents of the other analysed organic compounds (Table 6). In the studied case, phenol $(0.97 \mathrm{mg} / \mathrm{g})$ and methyl phenol $(1.17 \mathrm{mg} / \mathrm{g})$ are likely derived from the lipid fraction [34].

Upon comparing the results for the gaseous products obtained at 500 and $600^{\circ} \mathrm{C}$, a further increase in the component concentrations in the product (process gases) was noted (Fig. 7):

- $24 \%$ for methane,

- 4-6\% for carbon dioxide,

- $8 \%$ for hydrogen, and

- $4 \%$ for carbon monoxide. 


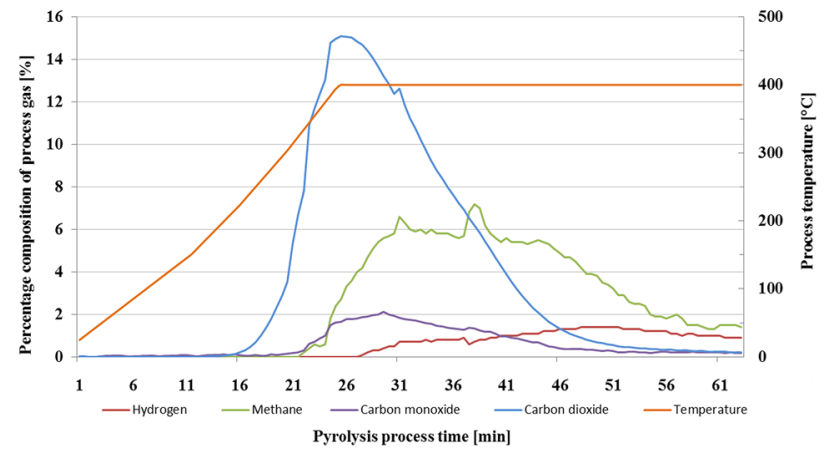

Fig. 4 Pyrolysis at $400^{\circ} \mathrm{C}-$ composition of the process gases

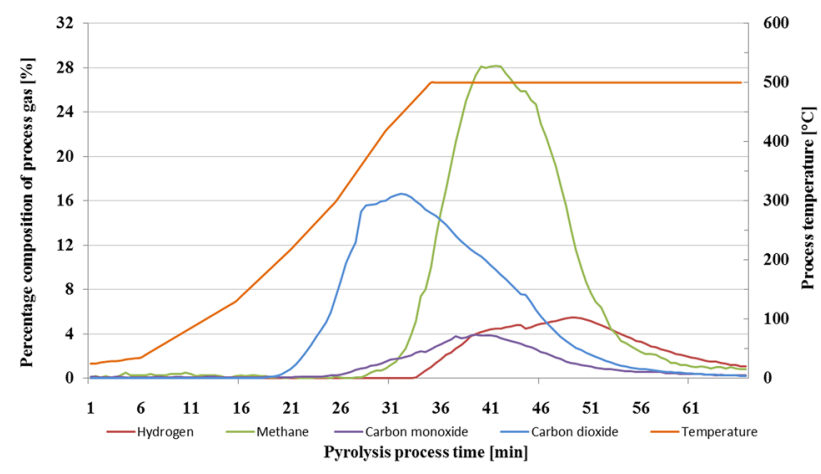

Fig. 5 Pyrolysis at $500^{\circ} \mathrm{C}$-composition of the process gases

As in the previous case, the temperature increase resulted in a $6 \%$ reduction in the yield of gaseous products, which reduced the amount of energy by almost $10 \%$. In the slow pyrolysis of Nannochloropsis at 500 and $600^{\circ} \mathrm{C}$, a significant quantity of methane, from 2 to $5 \%$ of the total weight of the feedstock, was observed. Compared to the slow pyrolysis at $500^{\circ} \mathrm{C}$ of other species of microalgae [35], the amount of methane ranged from 1 to $2 \%$ of the total weight of the feedstock. The recovered heating value of combustible gases from the slow pyrolysis of microalgae was comparable to that of other forms of biomass such as grass $(10.0 \mathrm{MJ} / \mathrm{kg})$, wood $(16.7 \mathrm{MJ} / \mathrm{kg})$, or rice husk $(7.4 \mathrm{MJ} / \mathrm{kg})$.

The results obtained under the slow pyrolysis of Nannochloropsis were compared with the results from the analytical pyrolysis. In the first pyrolysis step, at $200^{\circ} \mathrm{C}$ (Fig. 8), the following compounds evolve: trimethylamine (1.54 $\mathrm{min})$, acetone $(1.59 \mathrm{~min})$, isoxazole $(2.89 \mathrm{~min})$, 2-methylpiperidine (3.27 $\mathrm{min}), n, n$-dimethylaminoethanol (3.63 min), 2-furanmethanol (10.91 min), butanoic acid, and 4-hydroxy (15.35 $\mathrm{min})$ reported by other scientific research [36], hexadecane (39.56 min), phytol, acetate $(51.58 \mathrm{~min})$, nonadecane $(52.55 \mathrm{~min}), 1$-nonadecene (52.76 $\mathrm{min})$, tetradecanoic acid $(55.53 \mathrm{~min})$, eicosane (56.51 $\mathrm{min})$, 1-eicosene (56.72 $\mathrm{min})$, and palmitic acid, methyl ester (56.70 $\mathrm{min})$. Most of these compounds are separated from the studied biomass sample at $200^{\circ} \mathrm{C}$, which is why they are not visible after further increasing the temperature from 200 to $300^{\circ} \mathrm{C}$. In this temperature range, a small amount of phytol acetate $(51.58 \mathrm{~min})$ is observed.

The temperature increase from 300 to $400^{\circ} \mathrm{C}$ resulted in a further thermal decomposition of the studied material, whereby the following set of organic compounds is released: toluene (3.69 $\mathrm{min})$, resorcinol (16.85 $\mathrm{min}$ ) [37], 2,3,5-trimethylpyrrole (17.97 $\mathrm{min}$ ), and 2-ethyl-4-methyl$1 \mathrm{H}(18.46 \mathrm{~min})$ as reported by other scientific research [38, 39], phenol (21.21 min), $m$-cresol (25.78 min), indole (37.06 $\mathrm{min}), \beta$-methylindole (40.65 min), tetradecanoic acid (55.53 $\mathrm{min})$, hexadecanenitrile (59.18 $\mathrm{min})$, and other fatty acids $(66.78 \mathrm{~min})$. These chemical components are observed also in the temperature range between 400 and $500{ }^{\circ} \mathrm{C}$ but at lower concentrations. In the studied microalgae bio-oil, nitriles such as hexadecanenitrile, which are derived from fatty oxygenates, were analysed. In addition, protein-derived compounds such as indole were observed and may be produced from the decomposition of tryptophan amino acids [40].

The final temperature range of $500-600{ }^{\circ} \mathrm{C}$ resulted in a further thermal decomposition of the studied material, which released the following organic compounds: dodecane (19.21 min), 1-dodecene (19.31 min), 1-tridecene (24.71 $\mathrm{min})$, 2-hexyl-1-octene (24.79 $\mathrm{min})$, benzyl nitrile (26.11 min), hexadecane (39.56 $\mathrm{min})$, cetene $(39.73 \mathrm{~min})$, octadecane (41.64 min), heptadecane (44.13 $\mathrm{min})$, heptadecene $(44.27 \mathrm{~min})$, phytol acetate $(51.58 \mathrm{~min})$, nonadecane $(52.55 \mathrm{~min})$, 1-nonadecene $(52.76 \mathrm{~min})$, tetradecanoic acid (55.53 $\mathrm{min})$, eicosane (56.51 $\mathrm{min})$, 1-eicosene (56.72 $\mathrm{min})$, palmitic acid, methyl ester (56.70 min), oleanitrile (58.78 $\mathrm{min})$, hexadecanenitrile (59.18 $\mathrm{min})$, and heneicosane (60.36 $\mathrm{min})$.

All results from the Py-GC-MS analysis of Nannochloropsis treated with rapid pyrolysis between 200 and $600{ }^{\circ} \mathrm{C}$ are presented in Table 7. The main groups of aromatic hydrocarbons, heterocyclics, phenols, amines, amides, indoles, alkanes, and nitriles were found in the bio-oil. The length of the carbon chain in the bio-oil was in the range of C3-C22, and the boiling point of the oil fell in the range of $56^{\circ} \mathrm{C}$ for acetone to $356^{\circ} \mathrm{C}$ for heneicosane. Thus, the biooil property is between that of the oil from kerosene, diesel, and light gas oil [41]. Bio-oils (not only from microalgae pyrolysis but generally from the pyrolysis of biomass) are a complex mixture, highly oxygenated with a great amount of large-size molecules, which nearly involve all species of oxygenated organics, such as esters, ethers, aldehydes, ketones, phenols, carboxylic acids, and alcohols [42].

A comparison of the typical properties of fossil oils and bio-oils based on the slow and fast pyrolysis of wood 

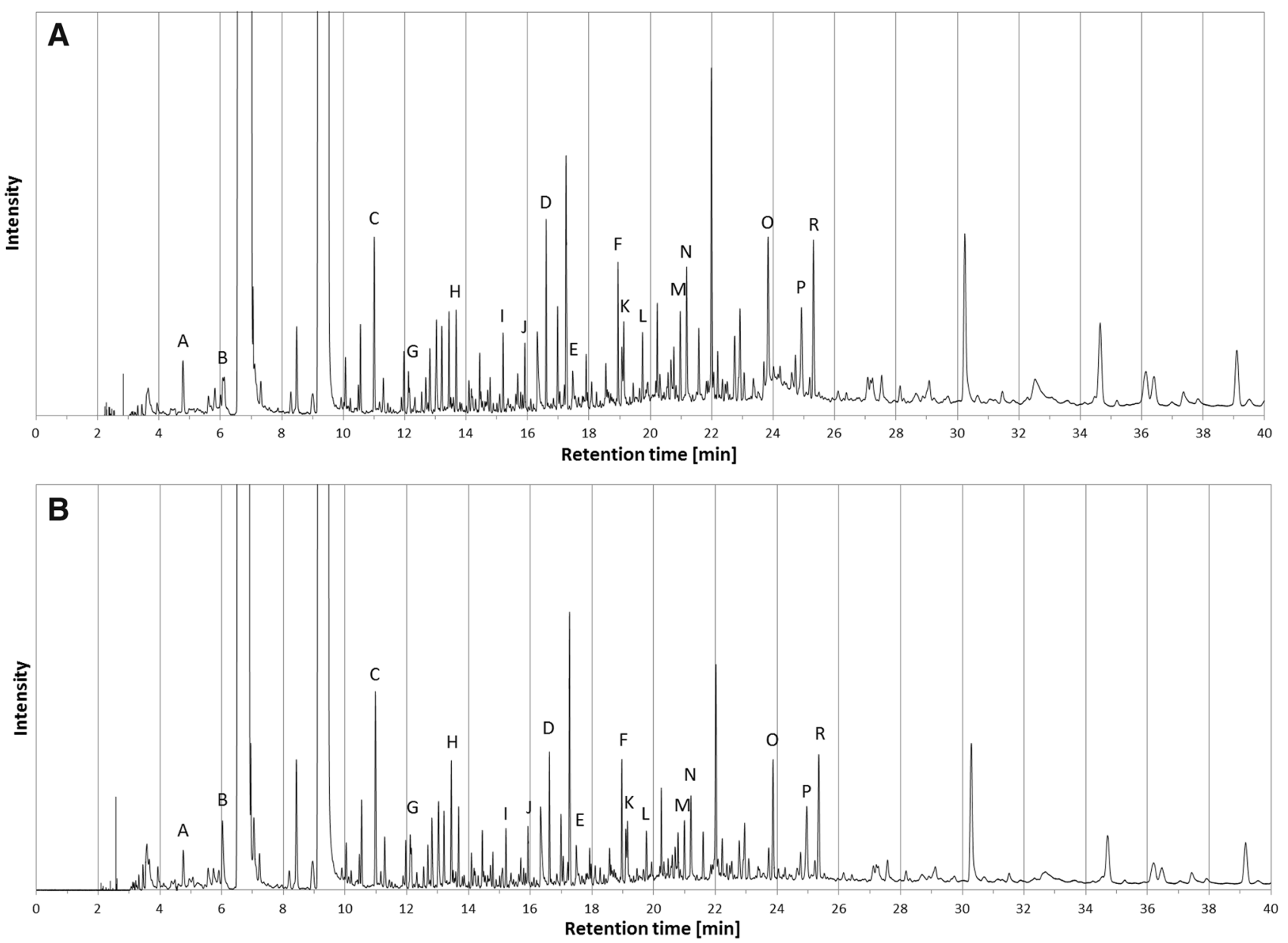

Fig. 6 Identified VOCs, alkanes, and alkenes in the liquid products (under $\mathbf{a} 500^{\circ} \mathrm{C}$ and $\mathbf{b} 600^{\circ} \mathrm{C}$ ) using a gas chromatograph. $A$ acetone, $B$ methanol, $C$ ethylbenzene, $D$ dodecane, $E$ styrene, $F n$-tetradecane,

biomass and microalgae is shown in Table 8 . The pyrolysis of biomass bio-oils usually yields higher oxygen concentrations than that of fossil oil. This causes bio-oils to be more reactive than and not as stable as fossil fuels, and

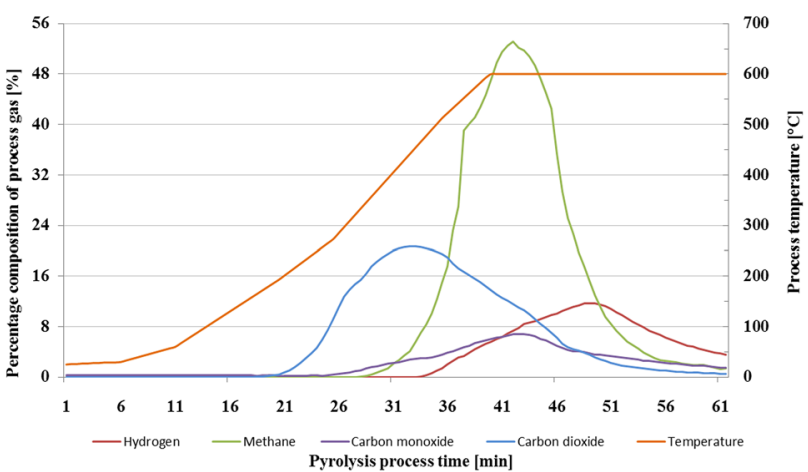

Fig. 7 Pyrolysis at $600^{\circ} \mathrm{C}$-composition of the process gases
$G n$-tetradecene, $H n$-pentadecane, $E n$-pentadecene, $I$ furfuryl alcohol, $J n$-heptadecane, $K n$-heptadecene, $L$ octadecane, $M$ hydroxyacetophenone, $N$ phenol, $O$ ethylphenol, $P$ 4-methylphenol

their characteristics change rapidly during condensation and under storage conditions [43]. To utilize bio-oils as a fuel for chemical feedstock sources, some improvements to their stability and high heating value are required. However, as shown in Table 8, the pyrolysis oil obtained from microalgae $N$. gaditana has a lower oxygen concentration (on average by $10 \%$ ) than the oil obtained during wood biomass pyrolysis. As a result, this oil will be more stable than bio-oil from wood biomass. Oils from microalgae pyrolysis have higher HHV values than wood bio-oil obtained from fast pyrolysis [45] but is lower than wood bio-oil from slow pyrolysis [44]. The HHV of bio-oil from the studied microalgae was between 18.2 and $21.5 \mathrm{MJ} / \mathrm{kg}$, depending on which temperature condition was utilized. In conclusion, the physical and chemical properties of microalgae bio-oil make it more suitable for fuel oil use than pyrolysis oils from lignocellulosic biomass feedstocks. 


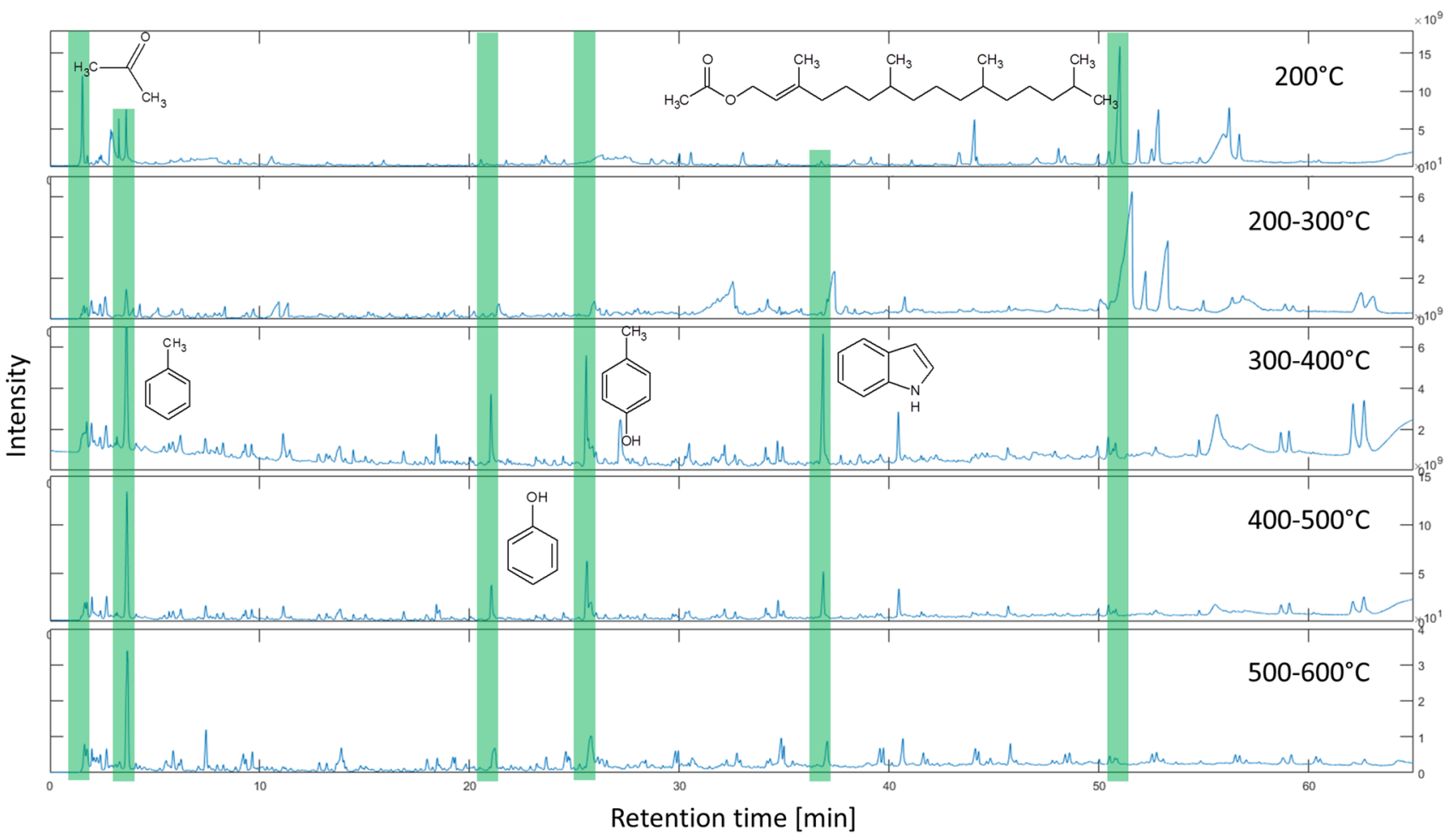

Fig. 8 Pyrogram results from Nannochloropsis pyrolysis in the temperature range between 200 and $600{ }^{\circ} \mathrm{C}$

\section{Degree of Coverage Heat Demand for the Pyrolysis Process of Microalgae Biomass}

To estimate the heat demand for the pyrolysis process, the following assumptions and conditions were used:

- the process was conducted in a steel retort in batch mode, and the capacity of the retort was $100 \mathrm{~g}$;

- the moisture content in the biomass intended for pyrolysis was established at five levels from 5 to $60 \%$;

- the final temperature of the process was established at three levels, namely 400,500 , and $600^{\circ} \mathrm{C}$;

- the number of liquid and gaseous products depended on the pyrolysis conditions (the results of the experiments);

- the liquid products had a water content of $4 \%$;

- the calorific values of the liquid and gaseous products depended on the pyrolysis temperature conditions (the results of the experiments);

- the calculations did not include the exothermic and endothermic heats of reaction occurring during the pyrolysis of the fuel, and it was assumed that their net energy effect was close to zero;

- the heat required to supply the reactor and to account for heat loss during the process, which was $15 \%$ of the heat required to perform pyrolysis;

- the calculations did not include the heat required to partially dry the biomass to a desired moisture content because it was assumed that the waste heat from the exhaust gases could be used for this purpose.

Analysis of the heat demand of the pyrolysis process allows the degree of energy self-sufficiency of this process to be estimated, which may be expressed by Eq. $(3,4)[44]$ :

$Q_{\text {self - suffic. }}=\frac{Q_{\text {products }}^{\mathrm{W}}}{Q_{\text {pyrol.process }}} \times 100$,

where $Q_{\text {self-suffic }}$ is the degree of energy self-sufficiency of the thermal conversion process $(\%), Q^{w}{ }_{\text {products }}$ is the heat energy from the burning products (e.g., gaseous products) $(\mathrm{MJ} / \mathrm{t})$, and $Q_{\text {pyrol. process }}$ is the heat energy demand of the pyrolysis process $(\mathrm{MJ} / \mathrm{t})$.

$Q_{\text {pyrol.process }}=\frac{c_{b} \cdot w_{b} \cdot T+\Delta H_{\mathrm{vap}} \cdot W^{a}}{1000}+Q_{\text {loss }}$,

where $c_{b}$ is the heat capacity of the biomass $(\mathrm{kJ} / \mathrm{kg} \mathrm{K}), w_{b}$ is the mass fraction of the biomass (\%), $T$ is the temperature of the thermal conversion process $\left({ }^{\circ} \mathrm{C}\right), \Delta H_{\text {vap }}$ is the enthalpy of water vaporization $(\mathrm{kJ} / \mathrm{kg}), W^{a}$ is the moisture content (\%), and $Q_{\text {loss }}$ is the heat loss from the thermal conversion process $(\mathrm{kJ} / \mathrm{kg})$.

During the pyrolysis of marine biomass, the efficiency is correlated with the degree of energy self-sufficiency and 
Table 7 Chemical components obtained from Py-GC-MS analysis in the five temperature ranges

\begin{tabular}{|c|c|c|c|c|c|c|c|c|}
\hline \multirow[t]{2}{*}{ Name } & \multicolumn{5}{|c|}{ Range of pyrolysis temperature } & \multirow[t]{2}{*}{ RT } & \multirow{2}{*}{ Formula } & \multirow[t]{2}{*}{ MW } \\
\hline & 200 & $200-300$ & $300-400$ & $400-500$ & $500-600$ & & & \\
\hline Trimethylamine & + & - & - & - & - & 1.54 & $\mathrm{C}_{3} \mathrm{H}_{9} \mathrm{~N}$ & 59.07 \\
\hline Acetone & + & - & - & - & - & 1.59 & $\mathrm{C}_{3} \mathrm{H}_{6} \mathrm{O}$ & 58.04 \\
\hline Propylethylene & - & - & + & + & + & 1.63 & $\mathrm{C}_{5} \mathrm{H}_{10}$ & 70.08 \\
\hline$\alpha$-Methylbutanal & - & - & + & + & + & 1.77 & $\mathrm{C}_{5} \mathrm{H}_{10} \mathrm{O}$ & 86.07 \\
\hline$\alpha$-Methylfuran & - & + & + & + & + & 1.99 & $\mathrm{C}_{5} \mathrm{H}_{6} \mathrm{O}$ & 82.04 \\
\hline Benzene & - & + & + & + & + & 2.39 & $\mathrm{C}_{6} \mathrm{H}_{6}$ & 78.05 \\
\hline 2,5-Dimethylfuran & - & - & + & + & + & 2.68 & $\mathrm{C}_{6} \mathrm{H}_{8} \mathrm{O}$ & 96.06 \\
\hline Isoxazole & + & - & - & - & - & 2.89 & $\mathrm{C}_{3} \mathrm{H}_{3} \mathrm{NO}$ & 69.02 \\
\hline 2-Methylpiperidine & + & - & - & - & - & 3.27 & $\mathrm{C}_{6} \mathrm{H}_{13} \mathrm{~N}$ & 99.10 \\
\hline $\mathrm{N}, \mathrm{N}$-dimethylaminoethanol & + & - & - & - & - & 3.63 & $\mathrm{C}_{4} \mathrm{H}_{11} \mathrm{NO}$ & 89.08 \\
\hline Toluene & - & + & + & + & + & 3.69 & $\mathrm{C}_{7} \mathrm{H}_{8}$ & 92.06 \\
\hline Pyridine & - & + & - & - & - & 4.28 & $\mathrm{C}_{5} \mathrm{H}_{5} \mathrm{~N}$ & 79.04 \\
\hline Propionic acid & - & - & + & - & - & 5.44 & $\mathrm{C}_{3} \mathrm{H}_{6} \mathrm{O}_{2}$ & 74.04 \\
\hline$\alpha$-Methylpyridine & - & - & + & - & - & 5.66 & $\mathrm{C}_{6} \mathrm{H}_{7} \mathrm{~N}$ & 93.06 \\
\hline Ethylbenzene & - & + & + & + & + & 5.87 & $\mathrm{C}_{8} \mathrm{H}_{10}$ & 106.08 \\
\hline Pyrrole & - & + & + & + & + & 6.25 & $\mathrm{C}_{4} \mathrm{H}_{5} \mathrm{~N}$ & 67.04 \\
\hline Styrene & - & + & + & + & + & 7.44 & $\mathrm{C}_{8} \mathrm{H}_{8}$ & 104.06 \\
\hline Cyclohexanol & - & - & + & - & - & 7.97 & $\mathrm{C}_{6} \mathrm{H}_{12} \mathrm{O}$ & 100.09 \\
\hline Cyclopenten-3-one & - & - & + & + & + & 7.97 & $\mathrm{C}_{5} \mathrm{H}_{6} \mathrm{O}$ & 82.04 \\
\hline Isoamyl cyanide & - & + & - & - & - & 8.34 & $\mathrm{C}_{6} \mathrm{H}_{11} \mathrm{~N}$ & 97.09 \\
\hline$n$-Propylbenzene & - & - & - & + & + & 9.22 & $\mathrm{C}_{9} \mathrm{H}_{12}$ & 120.09 \\
\hline$\alpha$-Methylpyrrole & - & - & + & + & + & 9.64 & $\mathrm{C}_{5} \mathrm{H}_{7} \mathrm{~N}$ & 81.06 \\
\hline 2-Furanmethanol & + & + & - & - & - & 10.91 & $\mathrm{C}_{5} \mathrm{H}_{6} \mathrm{O}_{2}$ & 98.04 \\
\hline Acetylfuran & - & + & - & - & - & 11.34 & $\mathrm{C}_{6} \mathrm{H}_{6} \mathrm{O}_{2}$ & 110.04 \\
\hline Pyrimidine & - & - & + & + & + & 13.88 & $\mathrm{C}_{4} \mathrm{H}_{4} \mathrm{~N}_{2}$ & 80.04 \\
\hline 2-Formyl-5-methylfuran & - & - & + & - & - & 14.45 & $\mathrm{C}_{6} \mathrm{H}_{6} \mathrm{O}_{2}$ & 110.04 \\
\hline Butanoic acid. 4-hydroxy- & + & - & - & - & - & 15.35 & $\mathrm{C}_{4} \mathrm{H}_{8} \mathrm{O}_{3}$ & 104.05 \\
\hline Resorcinol & - & - & + & - & - & 16.85 & $\mathrm{C}_{6} \mathrm{H}_{6} \mathrm{O}_{2}$ & 110.04 \\
\hline 2,3,5-Trimethylpyrrole & - & - & - & + & + & 17.97 & $\mathrm{C}_{7} \mathrm{H}_{11} \mathrm{~N}$ & 109.09 \\
\hline 2-Ethyl-4-methyl-1H-pyrrole & - & - & + & + & + & 18.46 & $\mathrm{C}_{7} \mathrm{H}_{11} \mathrm{~N}$ & 109.09 \\
\hline Dodecane & - & - & + & - & + & 19.21 & $\mathrm{C}_{12} \mathrm{H}_{26}$ & 170.20 \\
\hline 1-Dodecene & - & - & + & - & + & 19.31 & $\mathrm{C}_{12} \mathrm{H}_{24}$ & 168.19 \\
\hline Phenol & - & + & + & + & + & 21.21 & $\mathrm{C}_{6} \mathrm{H}_{6} \mathrm{O}$ & 94.04 \\
\hline$o$-Cresol & - & + & + & + & + & 23.66 & $\mathrm{C}_{7} \mathrm{H}_{8} \mathrm{O}$ & 108.06 \\
\hline Tridecane & - & - & - & + & + & 24.59 & $\mathrm{C}_{13} \mathrm{H}_{28}$ & 184.22 \\
\hline 1-Tridecene & - & - & - & - & + & 24.71 & $\mathrm{C}_{13} \mathrm{H}_{26}$ & 182.20 \\
\hline 2-Hexyl-1-octene & - & - & - & - & + & 24.79 & $\mathrm{C}_{14} \mathrm{H}_{28}$ & 196.22 \\
\hline$p$-Cresol & - & - & - & + & + & 25.78 & $\mathrm{C}_{7} \mathrm{H}_{8} \mathrm{O}$ & 108.06 \\
\hline Benzyl nitrile & - & - & - & - & + & 26.11 & $\mathrm{C}_{8} \mathrm{H}_{7} \mathrm{~N}$ & 117.06 \\
\hline Tetradecane & - & - & - & + & + & 29.82 & $\mathrm{C}_{14} \mathrm{H}_{30}$ & 198.23 \\
\hline$\alpha$-Tetradecene & - & - & - & + & + & 29.95 & $\mathrm{C}_{14} \mathrm{H}_{28}$ & 196.22 \\
\hline$p$-Ethylphenol & - & - & - & + & + & 30.63 & $\mathrm{C}_{8} \mathrm{H}_{10} \mathrm{O}$ & 122.07 \\
\hline Dianhydromannitol & - & + & + & + & - & 30.86 & $\mathrm{C}_{6} \mathrm{H}_{10} \mathrm{O}_{4}$ & 146.06 \\
\hline Benzenepropanenitrile & - & - & + & - & - & 32.16 & $\mathrm{C}_{9} \mathrm{H}_{9} \mathrm{~N}$ & 131.07 \\
\hline Pentadecane & - & - & + & + & + & 34.86 & $\mathrm{C}_{15} \mathrm{H}_{32}$ & 212.25 \\
\hline 1-Pentadecene & - & - & + & + & + & 34.98 & $\mathrm{C}_{15} \mathrm{H}_{30}$ & 210.23 \\
\hline Indole & - & + & + & + & + & 37.06 & $\mathrm{C}_{8} \mathrm{H}_{7} \mathrm{~N}$ & 117.06 \\
\hline Hexadecane & + & - & - & - & + & 39.56 & $\mathrm{C}_{16} \mathrm{H}_{34}$ & 226.27 \\
\hline Cetene & - & - & - & - & + & 39.73 & $\mathrm{C}_{16} \mathrm{H}_{32}$ & 224.25 \\
\hline
\end{tabular}


Table 7 (continued)

\begin{tabular}{|c|c|c|c|c|c|c|c|c|}
\hline \multirow[t]{2}{*}{ Name } & \multicolumn{5}{|c|}{ Range of pyrolysis temperature } & \multirow[t]{2}{*}{ RT } & \multirow[t]{2}{*}{ Formula } & \multirow[t]{2}{*}{ MW } \\
\hline & 200 & $200-300$ & $300-400$ & $400-500$ & $500-600$ & & & \\
\hline$\beta$-Methylindole & - & + & + & + & + & 40.65 & $\mathrm{C}_{9} \mathrm{H}_{9} \mathrm{~N}$ & 131.07 \\
\hline Octadecane & - & - & + & - & + & 41.64 & $\mathrm{C}_{18} \mathrm{H}_{38}$ & 254.30 \\
\hline Heptadecane & - & - & - & - & + & 44.13 & $\mathrm{C}_{17} \mathrm{H}_{36}$ & 240.28 \\
\hline Heptadecene & - & - & - & - & + & 44.27 & $\mathrm{C}_{17} \mathrm{H}_{34}$ & 238.27 \\
\hline Phytol acetate & + & + & - & - & - & 51.58 & $\mathrm{C}_{22} \mathrm{H}_{42} \mathrm{O}_{2}$ & 338.32 \\
\hline Nonadecane & - & - & - & - & + & 52.55 & $\mathrm{C}_{19} \mathrm{H}_{40}$ & 268.31 \\
\hline 1-Nonadecene & - & - & - & - & + & 52.76 & $\mathrm{C}_{19} \mathrm{H}_{38}$ & 266.30 \\
\hline Tetradecanoic acid & + & - & + & + & - & 55.53 & $\mathrm{C}_{14} \mathrm{H}_{28} \mathrm{O}_{2}$ & 228.21 \\
\hline Eicosane & - & - & - & - & + & 56.51 & $\mathrm{C}_{20} \mathrm{H}_{42}$ & 282.33 \\
\hline 1-Eicosene & - & - & - & - & + & 56.72 & $\mathrm{C}_{20} \mathrm{H}_{40}$ & 280.31 \\
\hline Palmitic acid. methyl ester & + & - & - & - & - & 56.70 & $\mathrm{C}_{17} \mathrm{H}_{34} \mathrm{O}_{2}$ & 270.26 \\
\hline Oleanitrile & - & - & + & + & + & 58.78 & $\mathrm{C}_{18} \mathrm{H}_{33} \mathrm{~N}$ & 263.26 \\
\hline Hexadecanenitrile & - & - & - & + & + & 59.18 & $\mathrm{C}_{16} \mathrm{H}_{31} \mathrm{~N}$ & 237.25 \\
\hline Heneicosane & - & - & - & - & + & 60.36 & $\mathrm{C}_{21} \mathrm{H}_{44}$ & 296.34 \\
\hline$n$-Hexadecanoic acid & - & + & - & - & - & 79.92 & $\mathrm{C}_{16} \mathrm{H}_{32} \mathrm{O}_{2}$ & 256.24 \\
\hline
\end{tabular}

Table 8 Comparison of typical properties of fossil oil and bio-oils from slow and fast pyrolysis of wood biomass and microalgae

\begin{tabular}{|c|c|c|c|c|c|c|c|c|c|}
\hline \multirow[t]{3}{*}{ Properties } & \multirow[t]{3}{*}{ Units } & \multicolumn{8}{|c|}{ Typical value } \\
\hline & & \multicolumn{5}{|c|}{ Slow pyrolysis } & \multicolumn{2}{|c|}{ Fast pyrolysis } & \multirow[t]{2}{*}{ Fossil oil } \\
\hline & & $\begin{array}{l}\text { Microalgae } \\
400^{\circ} \mathrm{C}\end{array}$ & $\begin{array}{l}\text { Microalgae } \\
500^{\circ} \mathrm{C}\end{array}$ & $\begin{array}{l}\text { Microalgae } \\
600^{\circ} \mathrm{C}\end{array}$ & Pine wood [44] & Alder wood [44] & Wood [45] & Microalgae [45] & \\
\hline $\mathrm{C}$ & $(\%)$ & 64.1 & 62.4 & 58.9 & 57.7 & 56.5 & 56.4 & 61.5 & $83.0-87.0$ \\
\hline $\mathrm{N}$ & & 15.4 & 13.1 & 12.5 & 0.1 & 0.4 & 0.1 & 9.8 & $0.01-0.7$ \\
\hline $\mathrm{H}$ & & 1.0 & 0.8 & 4.1 & 7.1 & 10.1 & 6.2 & 8.5 & $10.0-14.0$ \\
\hline $\mathrm{S}$ & & 0.0 & 0.9 & 0.8 & 0.1 & 0.1 & n.d. & n.d. & $0.05-5.0$ \\
\hline $\mathrm{O}$ & & 19.5 & 22.8 & 23.7 & 35.0 & 32.9 & 37.3 & 20.2 & $0.05-1.5$ \\
\hline HHV & $(\mathrm{MJ} / \mathrm{kg})$ & 19.6 & 18.2 & 21.5 & 24.8 & 28.8 & 21.0 & 29.0 & 42.0 \\
\hline
\end{tabular}

n.d. not determined

based on the pyrolysis conditions. The demand for heat and electricity may be minimized. Due to a wide range of biomass moisture content (particularly marine biomass, the moisture content of which can be greater than $70 \%$ ) in the energy balance calculation, we assumed that the process was conducted in the temperature range from 400 to $600^{\circ} \mathrm{C}$ with variable humidity in the range from 5 to $60 \%$. Under these conditions, dried algae biomass with a moisture content of $5 \%$ can maximize the yield of the solid and liquid fractions (under 500 and $600^{\circ} \mathrm{C}$ ) and can achieve a degree of energy self-sufficiency greater than $100 \%$ during pyrolysis using its gaseous products as a fuel to provide energy to the system (Fig. 9).

As shown in Fig. 9, the most unfavourable conditions for conducting an autothermal pyrolysis process are when the humidity of marine biomass exceeds $60 \%$. In this case, the degree of energy self-sufficiency of the process was
$<50 \%$. This effect can be minimized or even excluded for the tested biomass by utilizing not only the process gas for energy harvesting but also a portion of the char. According to our calculations, the amount sufficient for this case to achieve autothermal reaction of the assumed parameters is $35 \%$.

\section{Conclusion}

In the presented paper, the mass and energy balance and analysis of the pyrolysis products of $N$. gaditana marine biomass under different pyrolysis conditions were carried out. Both the mass/energy balance and characteristics of the pyrolysis products depend on temperature. At higher pyrolysis temperatures, more liquid and less gaseous products were observed. The liquid products from pyrolysis at 
Fig. 9 Degree of energy self-sufficiency of the biomass pyrolysis process depending on the biomass humidity content

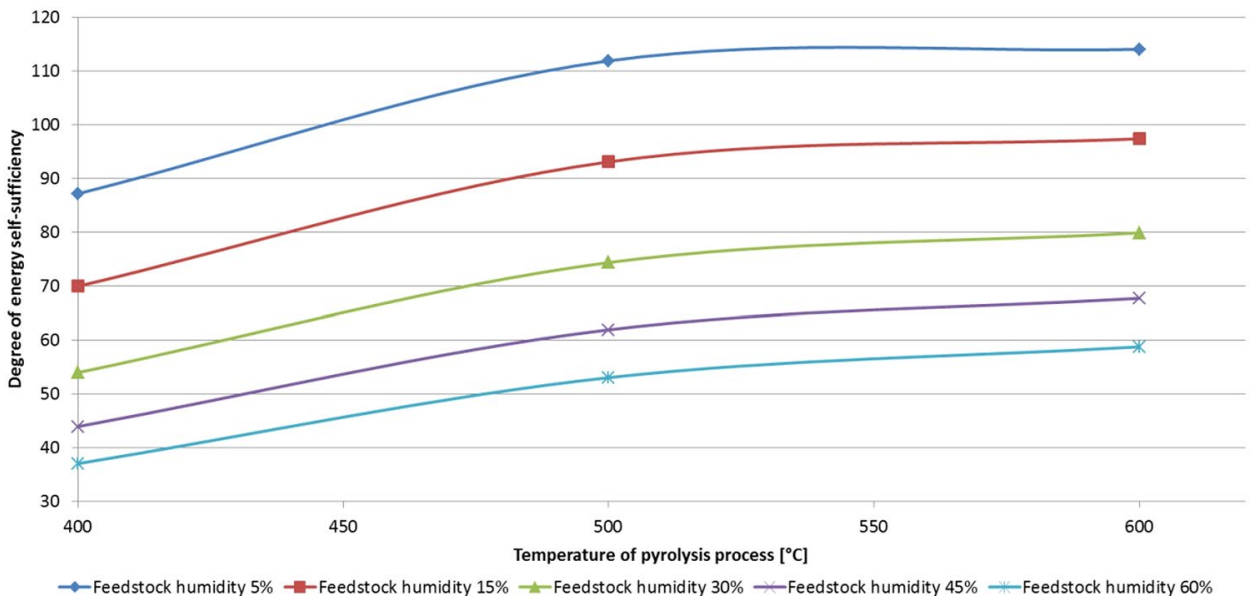

$500{ }^{\circ} \mathrm{C}$ contained the most alkenes and alkanes. The presence of hydrocarbons in the liquid product is indicative of the potential to use the bio-oil from $N$. gaditana pyrolysis for the production of biofuels and biocomponents. In the liquid products, several products of cellulose degradation (hydroxyacetone) or lignin degradation (phenols) were also identified. The ash content was determined from the biochar and was equal to approximately $68 \%$. The ash-rich biochar can be used as a fertilizer or biocomponent. The use of this ash as a fertilizer would be possible due to the low content of heavy metals in the tested algae biomass. In optimal pyrolysis conditions $\left(600^{\circ} \mathrm{C}\right)$, gaseous products are rich in methane (greater than 50\%). After purification, this gas can be used as a fuel or further processed for the production of methanol or hydrogen. An important factor contributing to the pyrolysis process is the degree of humidity of the feedstock. The higher moisture content of the material used in the pyrolysis process increases the amount of energy needed to carry out the process. The biomass of the marine species $N$. gaditana may have the potential for use in pyrolysis processes either to obtain methane-rich gases, for yielding a bio-oil that contains hydrocarbons, or for biochar which may be used in the fertilizer industry.

Acknowledgements The scientific work was co-funded by the Ministry of Science and Higher Education under the Iuventus Plus program in 2015-2016 (Project No. IP2014 041073) and was co-funded under the budget of research task No. 4 "Development of integrated technology of fuels and energy from biomass, agricultural waste, and others as part of the strategic programme of research and development: advanced technology of obtaining energy" provided by the NCBiR (SP/E/4/65786/10).

Open Access This article is distributed under the terms of the Creative Commons Attribution 4.0 International License (http:// creativecommons.org/licenses/by/4.0/), which permits unrestricted use, distribution, and reproduction in any medium, provided you give appropriate credit to the original author(s) and the source, provide a link to the Creative Commons license, and indicate if changes were made.

\section{References}

1. Saidur, R., Abdelaziz, E.A., Demirbas, A., Hossain, M.S., Mekhilef, S.: A review on biomass as a fuel for boilers. Renew. Sustain. Energy Rev. 15, 2262-2289 (2011)

2. Saidur, R., Boroumand, J.G., Mekhilef, S., Mohammed, H.A.: A review on exergy analysis of biomass based fuels. Renew. Sustain. Energy Rev. 16, 1217-1222 (2012)

3. Demirbas, A.: Potential applications of renewable energy sources. biomass combustion problems in boiler power systems and combustion related environmental issues. Prog. Energy Combust. 31, 171-192. (2005)

4. Jahirul, M.I., Rasul, M.G., Chowdhury, A.A., Ashwath, N.: Biofuels production through biomass pyrolysis-a technological review. Energies 5, 4952-5001 (2012)

5. Bentsen, N.S., Felby, C.: Biomass for energy in the European Union-a review of bioenergy resource assessments. Biotechnol. Biofuels 5, 25-35 (2012)

6. Aret, D.J., Wise, A., Gelman, R.: The status and prospects of renewable energy for combating global warming. Energy Econ. 33, 584-593 (2011)

7. John, R.P., Anisha, G.S., Nampoothiri, K.M., Pandey, A.: Micro and macroalgal biomass: a renewable source for bioethanol. Bioresour. Technol. 102, 186-193 (2011)

8. Moazami, N., Ashori, A., Ranjbar, R., Tangestani, M., Eghtesadi, R., Nejad, A.S.: Large-scale biodiesel production using microalgae biomass of Nannochloropsis. Biomass Bioenergy 39, 449$453(2012)$

9. Ward, A.J., Lewis, D.M., Green, F.B.: Anaerobic digestion of algae biomass: a review. Algal Res. 5, 04-214 (2014).

10. Skawinska, A., Lasek, J., Adamczyk, M.: Badanie procesów usuwania $\mathrm{CO}_{2}$ przy udziale mikroalg. Inż. Apar. Chem. 4, 292-293 (2014)

11. Dębowski, M., Zieliński, M., Grala, A., Dudek, M.: Algae biomass as an alternative substrate in biogas production technologies-review. Renew. Sustain. Energy Rev. 27, 596-604 (2013)

12. Chen, L., Liu, T., Zhang, W., Chen, X., Wang, J.: Biodiesel production from algae oil high in free fatty acids by two-step catalytic conversion. Bioresour. Technol. 111, 208-214 (2012)

13. Bridgwater, A.V.: Review of fast pyrolysis of biomass and product upgrading. Biomass Bioenergy 38, 68-94 (2012)

14. Atabani, A.E., Silitonga, A.S., Badruddin, I.A., Mahlia, T.M.I., Masjuki, H.H., Mekhilef, S.: A comprehensive review on biodiesel as an alternative energy resource and its characteristics. Renew. Sustain. Energy Rev. 16, 2070-2093 (2012) 
15. Lédé, J.: Cellulose pyrolysis kinetics: An historical review on the existence and role of intermediate active cellulose. J. Anal. Appl. Pyrolysis. 94, 17-32 (2012)

16. Plis, A., Lasek, J., Skawińska, A., Zuwała, J.: Thermochemical and kinetic analysis of the pyrolysis process in Cladophora glomerata algae. J. Anal. Appl. Pyrolysis. 115, 166-174 (2015)

17. Plis, A., Lasek, J., Zuwała, J., Yu, Ch., Iluk, A.: Combustion performance evaluation of using TGA and bubbling fluidized-bed combustor (batch reactor). J. Sust. Min. 15, 181-190 (2016)

18. Pan, P., Hu, H., Yang, W., Li, Y., Dong, L., Zhu, L., Tong, D., Qing, R., Fan, Y.: The direct pyrolysis and catalytic pyrolysis of Nannochloropsis sp. residue for renewable bio-oils. Bioresour. Technol. 12, 4593-4599 (2010)

19. Ceylan, S., Kazan, D.: Pyrolysis kinetics and thermal characteristics of microalgae Nannochloropsis oculata and Tetraselmis sp. Bioresour. Technol. 187, 1-5 (2015)

20. Sanchez-Silva, L., López-González, D., Villaseñor, J., Sánchez, P., Valverde, J. L.: Thermogravimetric-mass spectrometric analysis of lignocellulosic and marine biomass pyrolysis. Bioresour. Technol. 109, 163-172 (2012)

21. Guan, Y., Ma, Y., Zhang, K., Chen, H., Xu, G., Liu, W., Yang, Y.: Co-pyrolysis behaviors of energy grass and lignite. Energy Convers. Manag. 93, 32-140 (2015)

22. Bhavanam, A., Sastry, R.C.: Kinetic study of solid waste pyrolysis using distributed activation energy model. Bioresour. Technol. 178, 126-131 (2015)

23. Belotti, G., De Caprariis, B., De Filippis, P., Scarsella, M., Verdone, N: Effect of Chlorella vulgaris growing conditions on biooil production via fast pyrolysis. Biomass Bioenerg. 61, 187-195 (2014)

24. López-González, D., Fernandez-Lopez, M., Valverde, J.L., Sanchez-Silva L.: Kinetic analysis and thermal characterization of the microalgae combustion process by thermal analysis coupled to mass spectrometry. Appl. Energy 114, 227-237 (2014)

25. Sajdak, M., Słowik, K.: Use of plastic waste as a fuel in the copyrolysis of biomass: Part II. Variance analysis of the co-pyrolysis process. J. Anal. Appl. Pyrolysis. 109, 152-158 (2014)

26. PN-G-04512. Paliwa stałe-oznaczanie zawartości popiołu metodą wagową. (1920) (in Polish)

27. Muzyka, R., Topolnicka, T., Jarosz, P.: Laboratory procedure nr Q/LG/15 A. Oznaczenie zawartości azotu. węgla. wodoru. i siarki automatycznym analizatorem VarioMacroCube (2011) (in Polish)

28. Muzyka, R., Topolnicka, T., Jarosz, P.: Laboratory procedure nr Q/LG/16 A. Oznaczenie zawartości tlenu automatycznym analizatorem VarioMacroCube (2011) (in Polish)

29. Milne, T.A., Brennan, A.H., Glenn, B.H.: Sourcebook of methods of analysis for biomass and biomass conversion processes. Elsevier Applied Science, Amsterdam (1990)

30. Kim, S.-S., Ly H.V., Choi, G.-H., Kim, J., Woo, H.C.: Pyrolysis characteristics and kinetics of the alga Saccharina japonica. Bioresour. Technol. 123, 445-451 (2012)
31. Choi, J., Choi, J-W., Suh, D.J., Ha, J-M., Hwang, J.W., Jung, H.W., Lee, K-Y., Woo, H-C.: Production of brown algae pyrolysis oils for liquid biofuels depending on the chemical pretreatment methods. Energy Convers. Manag. 86, 371-378 (2014)

32. Vardon, D.R., Sharma, B.K., Blazina, G.V., Rajagopalan, K., Strathmann, T.J.: Thermochemical conversion of raw and defatted algal biomass via hydrothermal liquefaction and slow pyrolysis. Bioresour. Technol. 109, 178-187 (2012)

33. Wang, S., Wang, Q., Jiang, X., Han, X., Ji, H.: Compositional analysis of bio-oil derived from pyrolysis of seaweed. Energy Convers. Manag. 68, 273-280 (2013)

34. Harman-Ware, A.E., Morgan, T., Wilson, M., Crocker, M., Zhang, J., Liu, K., Stork, J., Debolt, S.: Microalgae as a renewable fuel source. Fast pyrolysis of Scenedesmus sp. Renew Energy 60, 625-632 (2013)

35. Grierson, S., Strezov, V., Ellem, G., Mcgregor, G., Herbertson, J.: Thermal characterisation of microalgae under slow pyrolysis conditions. J. Anal. Appl. Pyrolysis. 85, 118-123 (2009)

36. Ramsurn, H., Gupta, R.B.: Production of biocrude from biomass by acidic subcritical water followed by alkaline supercritical water two-step liquefaction. Energy Fuels 4, 2365-2375 (2012)

37. Zhang, Z., Sui, S., Wang, F., Wang, Q., Pittman, C.U Jr.: Catalytic conversion of bio-oil to oxygen-containing fuels by acidcatalyzed reaction with olefins and alcohols over silica sulfuric acid. Energies 6, 4531-4550 (2013)

38. Peng, Y., Wu, S.: Fast pyrolysis characteristics of sugarcane bagasse hemicellulose. Cellul. Chem. Technol. 45, 605-612 (2011)

39. Yang, X., Yuan, Ch., Xu, J., Zhang, W.: Co-pyrolysis of Chinese lignite and biomass in a vacuum reactor. Bioresour. Technol. 173, 1-5 (2014)

40. Tsuge, S., Matsubara, H.: High resolution pyrolysis-gas chromatography of proteins and related materials. J. Anal. Appl. Pyrolysis 8, 49-64 (1985)

41. Jones, J. D. S., Pujadó, P.P.: Handbook of petroleum processing. Springer, The Netherlands (2006)

42. Peng, W.M., Wu, Q.Y.: Production of fuels from biomass by pyrolysis. New Energy Sour. 22, 39-44 (2000)

43. Gercel, H. F.: The effect of a sweeping gas flow rate on the fast pyrolysis of biomass. Energy Sour. 24, 633-642 (2002)

44. Sajdak, M., Muzyka, R.: Use of plastic waste as a fuel in the copyrolysis of biomass. Part I: the effect of the addition of plastic waste on the process and products. J. Anal. Appl. Pyrolysis. 107, 267-275 (2014)

45. Miao, X., Wu, Q., Yang, Ch: Fast pyrolysis of microalgae to produce renewable fuels. J. Anal. Appl. Pyrolysis. 71, 855-863 (2004) 